\title{
Infrastruktur dan Teknologi Pada Kecamatan-Kecamatan di Kabupaten Bandung Dalam Mendukung Pelaksanaan Program Paten (Pelayanan Administrasi Terpadu Kecamatan)
}

\author{
Dedi Sukarno ${ }^{1}$
}

\begin{abstract}
ABSTRAK
Organisasi kecamatan di Kabupaten Bandung sebagai garda terdepan dalam melakukan tugas-tugas pemerintah daerah dalam melakukan pelayanan publik, memberdayakan masyarakat, dan melaksanakan pembangunan daerah juga harus memiliki faktor infrastruktur dan teknologi yang memadai. Faktor infrastruktur dan teknologi pada kecamatan ini sangat tergantung kepada sumber daya keuangan yang merupakan sumber pembiayaan bagi kegiatan organisasi. Tanpa adanya anggaran yang memadai, kecamatan sebagai suatu organisasi publik sulit untuk dapat melakukan aktivitasnya dalam melaksanakan tugas dan fungsinya guna mencapai tujuan.

Metode penelitian yang digunakan penulis untuk meneliti infrastruktur dan teknologi pada kecamatankecamatan di Kabupaten Bandung adalah metode penelitian kualitatif. Metode ini bertujuan untuk memahami berbagai faktor yang ada dalam infrastruktur dan teknologi pada kecamatan-kecamatan di Kabupaten Bandung. Alasan peneliti menggunakan metode penelitian kualitatif karena metode ini dapat digunakan untuk menemukan dan memahami hal-hal yang mendasar di balik fenomena infrastruktur dan teknologi pada kecamatan-kecamatan di Kabupaten Bandung.

Hasil penelitian menunjukkan bahwa saat ini kecamatan-kecamatan di Kabupaten Bandung belum memiliki strategi terencana yang dibutuhkan untuk meningkatkan standar-standar dari faktor-faktor organisasi yang bersifat fisik (infrastuktur dan peralatan) dan sumber daya keuangan. Para pimpinan kecamatan-kecamatan di Kabupaten Bandung juga belum memahami pendekatan yang lebih menyeluruh terhadap infrastruktur dan teknologi yang lebih bermanfaat dan diperlukan di masa yang akan datang. Dengan melihat keadaan perencanaan dan pengelolaan fasilitas, teknologi, dan keuangan oleh kecamatan-kecamatan di Kabupaten Bandung yang tergantung kepada APBD Pemerintah Kabupaten Bandung, maka anggaran yang ada di APBD Kabupaten Bandung belum merepresentasikan kebutuhan kecamatan secara lengkap untuk mencapai tujuantujuan organisasi kecamatan di lingkungan Pemerintah Kabupaten Bandung.
\end{abstract}

\section{ABSTRACT}

District organizations in Bandung Regency as the front guard in performing the duties of local government in performing public services, empowering communities, and implement regional development should also have adequate infrastructure and technology factors. The infrastructure and technology factors in this district organizations are highly dependent on the financial resources that are the source of financing for the organization's activities. Without an adequate budget, the sub-district as a public organization is difficult to perform its activities in carrying out its duties and functions in order to achieve its objectives.

The research method used by writer to research infrastructure and technology at district in Bandung Regency is qualitative research method. This method aims to understand the various factors that exist in infrastructure and technology in the districts in Bandung regency. The reason researcher use qualitative research method because this method can be used to discover and understand the basic things behind the phenomenon of infrastructure and technology in the sub-districts in Bandung regency.

The results show that currently the districts in Bandung Regency do not have the planned strategy which needed to improve the standards of organizational factors that are physical (infrastructure and equipment) and financial resources. The leaders of sub-districts in Bandung Regency also do not understand a more comprehensive approach to infrastructure and technology that is more useful and needed in the future. By looking at the state of planning and management of facilities, technology and finance by districts in Bandung regency that depend on Bandung Regency Government's budget, the budget in Bandung Regency's budget has not yet represented the complete need of district to achieve the objectives of district organization Bandung Regency Government.

${ }^{1}$ Dosen Pada Program Studi Administrasi Publik FISIP UNPAD 


\section{A. PENDAHULUAN}

Pada saat ini faktor infrastruktur dan teknologi telah menjadi bagian penting dari agenda sektor publik. Sektor publik selalu diiringi tuntutan untuk meningkatkan produktivitas, untuk memberikan layanan yang lebih baik kepada warga negara, dan untuk meningkatkan partisipasi masyarakat. Namun demikian, organisasi publik senantiasa menghadapi tantangan globalisasi, teknologi, peningkatan mobilitas manusia, barang dan jasa, perkembangan zaman, perubahan sosial, dan perubahan iklim yang sekarang lebih mungkin daripada sebelumnya untuk memiliki dampak yang lebih mendasar tentang peran sektor publik. Hal ini memunculkan tuntutan baru bagi sektor publik untuk meningkatkan keberadaan faktor infrastruktur dan teknologi dalam mendukung aktivitas-aktivitas dalam organisasinya.

Kecamatan di Kabupaten Bandung telah mendapatkan instruksi dari Kementerian Dalam Negeri untuk melaksanakan program Pelayanan Administrasi Terpadu Kecamatan atau disingkat Paten $^{2}$ yang merupakan penyelenggaraan pelayanan publik di kecamatan dari tahap permohonan sampai ke tahap terbitnya dokumen dalam satu tempat. Kementerian Dalam Negeri membuat dua kebijakan terkait dengan Paten ini, yaitu Permendagri Nomor 4 Tahun 2010 tentang Pedoman Pelayanan Administrasi Terpadu Kecamatan dan Kepmendagri Nomor 138-270 Tahun 2010 tentang Petunjuk Teknis Pedoman Pelayanan Administrasi Terpadu Kecamatan. Pemerintah Kabupaten Bandung menyambut kebijakan ini dengan baik, dimana satu tahun kemudian Pemerintah Kabupaten Bandung menerbitkan dua kebijakan yang mengoperasionalisasikan Permendagri tersebut, yaitu dengan diterbitkannya Keputusan Bupati
Bandung Nomor 138/Kep.368-Pemum/2011 tentang Pembentukan Tim Teknis Pelayanan Administrasi Terpadu Kecamatan (Paten) dan kemudian disusul dengan terbitnya Keputusan Bupati Bandung Nomor 138/Kep.420-Pemum/2011 tentang Penetapan Kecamatan Sebagai Penyelenggara Pelayanan Administrasi Terpadu Kecamatan (Paten).

Maksud dari penyelenggaraan Paten di Kabupaten Bandung adalah mewujudkan Kecamatan sebagai pusat pelayanan masyarakat dan menjadi simpul pelayanan bagi instansi pelayanan terpadu di Kabupaten Bandung ${ }^{3}$. Sedangkan tujuan pelaksanaan Paten oleh kecamatan di Kabupaten Bandung adalah untuk meningkatkan kualitas pelayanan publik dan mendekatkan pelayanan kepada masyarakat Kabupaten Bandung 4 . Adapun pejabat penyelenggara ${ }^{5}$ Paten terdiri atas: Camat di Kabupaten Bandung beserta Sekretaris Kecamatan dan Kepala seksi yang membidangi pelayanan administrasi.

Pelayanan Administrasi Terpadu Kecamatan atau dikenal dengan istilah Paten disertai dukungan pembiayaan beserta sarana dan prasarananya. Setiap Kecamatan di Kabupaten Bandung diberikan dana operasional pada tahap awal yang cukup besar untuk pelaksanaan Paten ini, yaitu sebesar Rp. 250.000.000,00 (dua ratus lima puluh juta rupiah) per Kecamatan. Untuk selanjutnya biaya penyelenggaraan Paten dibebankan pada Anggaran Pendapatan dan Belanja Daerah ${ }^{6}$. Biaya penyelenggaraan Paten merupakan bagian yang tidak terpisahkan dari rencana kerja dan anggaran Kecamatan.

Dalam pedoman tertulis tentang Paten disebutkan bahwa Kecamatan bukan hanya berperan sebagai percepatan peningkatan kualitas pelayanan publik, tetapi berperan pula sebagai katalisator guna menciptakan pelayanan prima

\footnotetext{
5 Pelaksanaan ini sejalan dengan isi Peraturan Menteri Dalam Negeri Nomor 4 Tahun 2010 Tentang Pedoman Pelayanan Administrasi Terpadu Kecamatan, Bab V Pasal 15.

${ }^{6}$ Penetapan anggaran ini sejalan dengan isi Peraturan Menteri Dalam Negeri Nomor 4 Tahun 2010 Tentang Pedoman Pelayanan Administrasi Terpadu Kecamatan, Bab VI Pasal 21 Ayat 1 - Ayat 2.

2 Dapat dilihat dalam Peraturan Menteri Dalam Negeri Nomor 4 Tahun 2010 Tentang Pedoman Pelayanan Administrasi

Terpadu Kecamatan Pasal 1 Ayat 4

${ }^{3}$ Hal ini sejalan dengan isi Peraturan Menteri Dalam Negeri Nomor 4 Tahun 2010 Tentang Pedoman Pelayanan Administrasi Terpadu Kecamatan, Pasal 3.

${ }^{4}$ Dapat dibandingkan dengan isi Peraturan Menteri Dalam
} Negeri Nomor 4 Tahun 2010 Tentang Pedoman Pelayanan Administrasi Terpadu Kecamatan, Pasal 4. 
melalui konsep pelayanan one stop service atau pelayanan satu pintu. Pelaksanaan Paten ini sejalan dengan tujuan dari kebijakan otonomi daerah yang bertujuan mewujudkan peningkatan pelayanan dan kesejahteraan lebih baik, artinya pelayanan diberikan haruslah suatu layanan yang memenuhi standar kualitas tertentu yang dielaborasi melalui paradigma new public services dimana publik dipandang sebagai citizen dan shareholder sehingga pelayanan yang diberikan sesuai dengan kepentingan publik.

Organisasi kecamatan di Kabupaten Bandung sebagai garda terdepan dalam melakukan tugas-tugas pemerintah daerah dalam melakukan pelayanan publik, memberdayakan masyarakat, dan melaksanakan pembangunan daerah juga harus memiliki faktor infrastruktur dan teknologi yang memadai. Faktor infrastruktur dan teknologi pada kecamatan ini sangat tergantung kepada sumber daya keuangan yang merupakan sumber pembiayaan bagi kegiatan organisasi, dengan demikian sumber daya keuangan ini dapat disamakan dengan ketersediaan anggaran (budget). Tanpa adanya anggaran yang memadai, kecamatan sebagai suatu organisasi publik sulit untuk dapat melakukan aktivitasnya dalam melaksanakan tugas dan fungsinya guna mencapai tujuan. Menurut Mardiasmo (2002: 121) ada tiga hal penting terkait dengan fungsi anggaran sektor publik. Pertama, anggaran merupakan alat bagi pemerintah untuk mengarahkan pembangunan, manajemen keseimbangan dan meningkatkan kesejahteraan masyarakat. Kedua, karena adanya kebutuhan dan keinginan dari masyarakat yang banyak disatu sisi, sementara sumber daya keuangan yang ada sangat terbatas. Ketiga, anggaran merupakan bentuk tanggung jawab pemerintah terhadap rakyat. Dengan demikian anggaran publik merupakan alat pelaksanaan akuntabilitas publik oleh lembaga publik. Hal di atas sejalan dengan yang dikemukakan oleh Rubbin, (2010:343), bahwa: "the essence of budgeting is that it allocates scarce resourcess and hence implies chice between potential object of expenditure. Budgeting implies balance and it requires some kind of decission-making process" Budgeting merupakan "the means by which public official allocate and raise resourcess to achieve social objectives" (Starling, 2005:513), atau sebagai "The allocations of expenditures among different pupposes so as to achieve greater return" (key, 1994:283). Karena kedudukannya yang penting, anggaran merupakan alat yang paling efektif untuk mempengaruhi perilaku organisasi (Cohen dan Eimicke, 2002:186).

Kelangkaan sumber daya pada sektor publik, membuat organisasi publik untuk dapat mengalokasikan secara cermat terhadap sektorsektor yang dianggap penting dan perlu mendapatkan perhatian. Di negara yang menganut sistem desentralisasi dan desentralisasi fiskal, sebagian besar pengeluaran publik berada pada tingkat daerah (Avellaneda, 2009:469). Namun demikian, karena sebagian besar pemerintah daerah memiliki keterbatasan dalam hal sumber daya keuangan, maka kecamatan sebagai perangkat daerah yang terbawah sangat tergantung kepada alokasi pemerintah daerah dalam hal sumber daya keuangan untuk pengembangan infrastruktur dan teknologinya. Dalam hal infrastruktur, Horton menjelaskan bahwa:

Operational infrastructure refers to such things as the amount, type, and quality of buildings, vehicles, and supplies needed for the operation of the organization. However, managers must also consider future infrastructure needs and seek support and resources to obtain these. They also have to think about adapting infrastructure to meet site-specific conditions or emerging needs. (Horton, 2003:26)

Dengan demikian infrastruktur ini meliputi berbagai hal, seperti gedung, kendaraan, dan berbagai suplai yang mendukung pemenuhan kebutuhan organisasi untuk melaksanakan aktivitas operasionalnya. Selanjutnya Horton menjelaskan pula bahwa perlu adanya strategi deliberasi untuk infrastruktur ini, yaitu:

A deliberate strategy was also needed to raise the standards of its physical (infrastructure and equipment) and 
financial resources. The participants of the study now understand that a more holistic approach to capacity development would have been more useful and is required in the future. (Horton, 2003:15)

Berdasarkan penjelasan di atas maka strategi terencana juga dibutuhkan untuk meningkatkan standar-standar dari faktor-faktor organisasi yang bersifat fisik (infrastuktur dan peralatan) dan sumber daya keuangan. Saat ini para pimpinan organisasi juga harus memahami bahwa diperlukan sebuah pendekatan yang lebih menyeluruh terhadap kapasitas organisasi yang lebih bermanfaat dan diperlukan di masa yang akan datang.

\section{METODE PENELITIAN}

Metode penelitian yang digunakan penulis untuk meneliti infrastruktur dan teknologi pada kecamatan-kecamatan di Kabupaten Bandung adalah metode penelitian kualitatif. Metode ini bertujuan untuk memahami berbagai faktor yang ada dalam infrastruktur dan teknologi pada kecamatan-kecamatan di Kabupaten Bandung. Alasan peneliti menggunakan metode penelitian kualitatif karena metode ini dapat digunakan untuk menemukan dan memahami hal-hal yang mendasar di balik fenomena infrastruktur dan teknologi pada kecamatankecamatan di Kabupaten Bandung.

Latar penelitian ini adalah tempat dan situasi dimana wawancara dan observasi dilakukan, yaitu tempat dan situasi yang berkaitan dengan organisasi kecamatan di Kabupaten Bandung, yaitu di kantor kecamatan. Situasi sosial ini di dalamnya adalah subjek penelitian ini yaitu informan (camat dan sekretaris kecamatan) yang terlibat didalam fokus penelitian.

Informan dari setiap Kecamatan di Kabupaten Bandung yang ditentukan dalam penelitian ini berdasarkan kriteria yang peneliti tetapkan, yaitu Kecamatan yang memiliki jarak terjauh dari ibukota kabupaten, yaitu: Kecamatan
Nagreg dan Kecamatan Rancabali, Kecamatan yang memiliki jarak terdekat dari ibukota kabupaten, yaitu: Kecamatan Baleendah dan Kecamatan Margaasih, Kecamatan yang memiliki jumlah penduduk yang tinggi, yaitu: Kecamatan Margahayu dan Kecamatan Dayeuhkolot, Kecamatan yang memiliki jumlah penduduk yang rendah, yaitu: Kecamatan Cilengkrang dan Kecamatan Pameungpeuk, Kecamatan yang memiliki laju pertumbuhan ekonomi tinggi, yaitu: Kecamatan Cimenyan, Kecamatan Majalaya, dan Kecamatan Pangalengan, Kecamatan yang memiliki laju pertumbuhan ekonomi rendah, yaitu: Kecamatan Cikancung, Kecamatan Cangkuang, dan Kecamatan Ibun, Kecamatan yang memiliki partisipasi sektor swasta yang tinggi, yaitu: Kecamatan Katapang dan Kecamatan Rancaekek, dan Kecamatan yang memiliki partisipasi sektor swasta yang rendah, yaitu: Kecamatan Cicalengka dan Kecamatan Arjasari. Selain itu, peneliti juga telah melakukan wawancara dengan Staf Ahli Bupati Bandung, Bagian Pemerintahan Umum (Setda), Bagian Organisasi (Setda), Dinas Kependudukan dan Catatan Sipil, Badan Perencanaan Pembangunan Kabupaten Bandung, dan anggota DPRD Kabupaten Bandung.

\section{PEMBAHASAN}

\subsection{Ketersediaan Teknologi (Availability of Technology)}

Faktor infrastruktur dan teknologi merupakan perangkat yang menjadi tulang punggung bagi kemampuan organisasi publik untuk dapat mengelola elemen organisasi yang terkait dengan operasi kegiatan sehari-hari, misalnya database, tindakan manual, aturan teknis, prosedur, dan teknologi informasi. Di dalam faktor infrastruktur dan teknologi ini, tantangan yang paling penting bahwa semua aspek akan berhubungan langsung ke teknologi informasi.

Dalam hal ketersediaan teknologi di Kecamatan Arjasari ${ }^{7}$ sudah memadai, tetapi

\footnotetext{
Analisis berdasarkan hasil wawancara dengan Sekretaris Kecamatan Arjasari
} 
masih terdapat kekurangan terutama dalam pengintregasian pelayanan. Teknologi yang tersedia di Kecamatan Arjasari untuk pelayanan standar memang sudah memadai, tetapi untuk pelaksanaan Program Paten (Pelayanan Administrasi Terpadu Kecamatan) masih perlu ditambah dan ditingkatkan. Sedangkan di Kecamatan Baleendah $^{8}$ memang tidak banyak jumlahnya, namun sudah dirasa cukup menunjang seluruh ativitas yang ada di Kecamatan Baleendah, walaupun pegawai melakukannya dengan bebean kerja yang lebih berat dalam pelayanan $e$-KTP. Untuk kondisi ketersediaan teknologi di Kecamatan Cangkuang $^{9}$ terdapat sebuah ruangan komputer untuk mengolah data yang mempermudah pekerjaan Kecamatan dan adanya CCTV untuk memantau aktivitas pegawai kecamatan. Ketersediaan teknologi di Kecamatan Cangkuang ini sudah cukup menunjang aktivitas di Kecamatan Cangkuang, meskipun tidak semua pegawai bisa menjalankannya dengan baik, sehingga beberapa unit komputer diletakkan dalam satu ruangan namun hanya dikelola oleh seorang pegawai. Perangkat AC, CCTV, serta internet juga mempengaruhi efektivitas kinerja dan mendukung pekerjaan pegawai.

Ketersediaan teknologi di Kecamatan Cicalengka ${ }^{10}$ sudah cukup banyak, diantaranya terdapat perangkat komputer yang digunakan untuk menginput data yang masuk dan data yang keluar, sehingga dengan menggunakan komputer dapat mempermudah pada pegawai untuk menginputnya. Kemudian ada mesin antrian elektronik, sehingga mempermudah masyarakat untuk mendapatkan layanan dari pihak kecamatan tanpa berdesak desakan. Mesin ini seperti halnya yang diterapkan pada perusahaan perbankan yang ada di Indonesia sehingga masyarakat hanya mengambil nomor antrian dari

\footnotetext{
8 Analisis berdasarkan hasil wawancara dengan Camat Kecamatan Bale Endah

9 Analisis berdasarkan hasil wawancara dengan Sekretaris Kecamatan Cangkuang

10 Analisis berdasarkan hasil wawancara dengan Sekretaris Kecamatan Cangkuang

11 Analisis berdasarkan hasil wawancara dengan Camat Cikancung
}

mesin elektronik antrian dan kemudian bisa menunggu sambil duduk, tanpa berdesakdesakan dengan masyarakat yang lain. Selain itu terdapat juga anjungan informasi secara elektronik dimana masyarakat bisa mencari informasi tentang kecamatan pada anjungan informasi elektronik tersebut, sehingga mempermudah masayarakat dalam mendapatkan informasi. Namun, karena pelaksanaan Paten di Kecamatan Cicalengka baru berjalan selama satu tahun, jadi saat ini masih dalam proses pengadaan sarana Kecamatan Cicalengka, seperti ketersediaan jumlah komputer yang masih kurang.

Ketersediaan teknologi di Kecamatan Cikancung ${ }^{11}$ hanya terdapat tiga unit komputer dan fingerprint untuk pencatatan absensi pegawai. Secara keseluruhan, ketersediaan teknologi di Kecamatan Cikancung saat ini memang sudah cukup menunjang aktivitas yang ada, hanya saja fasilitas sarana dan prasarana teknologi yang ada belum mampu memenuhi pelayanan prima bagi masyarakat. Sedangkan di Kecamatan Cilengkrang ${ }^{12}$ sudah cukup memadai dan menunjang bagi pekerjaan dan aktivitas Kecamatan Cilengkrang. Hal tersebut didasarkan pada kebutuhan teknologi dalam pelayanan masyarakat di Kecamatan Cilengkrang sudah terpenuhi. Kemudian, untuk ketersediaan komputer di Kecamatan Cimenyan, ${ }^{13}$, terdapat sebuah ruangan komputer untuk mengolah data yang mempermudah pekerjaan Kecamatan. Ketersediaan teknologi ini sudah cukup menunjang pekerjaan dan aktivitas di kecamatan Cimenyan, meskipun tidak semua pegawai bisa menjalankannya dengan baik.

Dalam hal ketersediaan teknologi di Kecamatan Dayeuhkolot ${ }^{14}$ sudah ada, namun jumlahnya belum banyak. Ketersedian teknologi ini masih dirasa belum maksimal pemanfaatannya dalam menunjang aktivitas di

\footnotetext{
12 Analisis berdasarkan hasil wawancara dengan Sekeretaris Kecamatan Cilengkrang

13 Analisis berdasarkan hasil wawancara dengan Camat Cimenyan

${ }^{14}$ Analisis berdasarkan hasil wawancara dengan Camat Dayeuh Kolot
} 
Kecamatan Dayeuhkolot, hal ini dikarenakan jumlah teknologi yang masih sedikit, sehingga tidak semua aktivitas di Kecamatan Dayeuhkolot memanfaatkan teknologi yang ada. Sedangkan di Kecamatan Katapang ${ }^{15}$ sudah terdapat perangkat komputer dan jaringan internet. Namun ketersediaan teknologi ini juga dirasa belum dapat menunjang seluruh aktivitas di Kecamatan Katapang, dikarenakan jumlah perangkat komputer yang masih sedikit untuk menangani seluruh aktivitas Kecamatan katapang yang banyak, seperti halnya menginput data masyarakat.

Untuk ketersediaan teknologi di Kecamatan Majalaya ${ }^{16}$ selangkah lebih maju dibanding dengan beberapa kecamatan yang ada di wilayah Kabupaten Bandung. Dimana setiap perangkat baik dari top level manajemen (Camat, Sekcam), kepala sub bagian dan kepala seksi masing-masing memiliki satu unit PC yang diharapkan mampu mendukung aktivitas kerja. Ditambah untuk bagian front office juga terdapat satu unit perangkat PC. Kantor Kecamatan Majalaya juga memiliki sudah dilengkapi dengan jaringan internet. Namun yang dirasa masih kurang di Kecamatan Majalaya adalah belum tersedianya mesin fotokopi. Walaupun belum memliki sarana dan prasarana yang memiliki teknologi modern, seperti fingerprint, namun ketersediaan teknologi yang sudah ada sangat membantu kemajuan pelayanan masyarakat dan mendukung pelaksanaan program Paten di Kecamatan Majalaya.

Ketersediaan teknologi di Kecamatan Margaasih $^{17}$ sudah memadai. Hal tersebut didukung juga oleh pelaksanaan Program Paten, sehingga aktivitas di kecamatan sudah terintegrasi secara online. Seperti contohnya jika kita mencari referensi peraturan kita dapat langsung mengaksesnya di internet. Hal tersebut tentunya sangat mempermudah dan menunjang pegawai dalam menjalankan tugas. Selain itu,

15 Analisis berdasarkan hasil wawancara dengan Sekretaris Kecamatan Katapang

16 Analisis berdasarkan hasil wawancara dengan Sekretaris Kecamatan Majalaya

17 Analisis berdasarkan hasil wawancara dengan Camat Margaasih untuk berinteraksi dengan 12 kecamatan juga sudah sangat membantu dalam mempermudah komunikasi antar seluruh pihak yang terkait, namun sayangnya belum semuanya Kecamatan di Kabupaten Bandung dapat terintegrasi, karena baru 12 dari 31 kecamatan yang sudah melaksanakan Program Paten.

Sedangkan untuk ketersediaan teknologi di Kecamatan Margahayu ${ }^{18}$ belum cukup memadai. Keberadaan teknologi yang tersedia di Kecamatan Margahayu juga belum dapat menunjang seluruh aktivitas di Kecamatan Margahayu karena kurangnya SDM yang kompeten. Hal serupa juga ada di Kecamatan Nagreg ${ }^{19}$ yang masih sangat minim, sebab baru terdapat dua perangkat komputer yang digunakan oleh seluruh pegawai di Kantor Kecamatan Nagreg. Dengan hanya tersedianya 2 perangkat komputer tersebut tentunya belum dapat menunjang seluruh aktivitas yang ada di Kecamatan Nagreg.

Dalam hal ketersedian teknologi di Kecamatan Pamengpeuk ${ }^{20}$ masih terbilang cukup memadai, sebab pemerintah menganggarkan dana untuk menyediakan fasilitas baru dalam menunjang penyelenggaraan Paten, seperti ruangan baru untuk pelayanan masyarakat dan juga anjungan informasi. Selain itu tersedia pula beberapa komputer untuk memudahkan para pegawai dalam bekerja. Ketersediaan teknologi ini sangat menunjang aktivitas di Kecamatan Nagreg, apalagi dengan diselenggarakannya sistem Paten, fasilitas teknologi menjadi alat utama untuk mempermudah pelaksanaan agar semakin cepat dan efisien. Selain itu informasi kepada masyarakat pun menjadi mudah disebar melalui website dan email kecamatan sehingga mempermudah masyarakat untuk mengakses segala informasi apapun mengenai pelayanan di Kecamatan Pameungpeuk.

Namun dalam hal ketersediaan teknologi di Kecamatan Pangalengan ${ }^{21}$ masih terbilang

18 Analisis berdasarkan hasil wawancara dengan Sekretaris Kecamatan Margahayu

19 Analisis berdasarkan hasil wawancara dengan Camat Nagreg

20 Analisis berdasarkan hasil wawancara dengan Camat Pamengpeuk

21 Analisis berdasarkan hasil wawancara dengan Sekretaris Kecamatan Pangalengan 
sederhana, misalnya komputer, printer yang sekaligus bisa dijadikan alat fotokopi. Ketersediaan teknologi di Kecamatan Pangalengan belum dapat menunjang aktivitas kecamatan, hal ini dikarenakan keterbatasan sarana prasana teknologi yang tersedia. Sama halnya di Kecamatan Rancaekek ${ }^{22}$ belum memadai, hal tersebut didasarkan pada ketersediaan jumlah perangkat komputer yang kurang. Tidak semua Kepala Seksi (Kasi) di Kecamatan Rancaekek memiliki komputer, bahkan salah satu Kasi di Kecamatan Rancaekek harus berusaha keras mencari peluang lainnya untuk dapat membeli laptop karena tuntutan pekerjaan yang sudah harus terkomputerisasi tetapi perangkat komputer yang dibutuhkan belum ada. Ketersedian teknologi di Kecamatan Rancaekek ini memang sangat membantu bagi beberapa pegawai yang bisa menggunakannya, namun masih menghambat kegiatannya karena terkadang tidak semua pegawai kecamatan dapat mengoperasikannya, sehingga harus meminta bantuan kepada pegawai lain yang dianggap mampu, tentunya hal ini dapat menghambat kinerja para pegawai Kecamatan Rancaekek.

Sedangkan untuk ketersedian teknologi di Kecamatan Rancabali ${ }^{23}$ sudah memadai dan cukup maju dengan adanya dukungan unit komputer yang sudah terhubung dengan jaringan internet, sehingga memudahkan pengelolaan data secara online seperti pada saat pembuatan $e$-KTP. Ketersediaan teknologi ini sudah menunjang aktivitas di Kecamatan Rancabali, karena teknologi yang ada mampu memudahkan pekerjaan yang sebelumnya dilakukan secara manual, walaupun penerapannya belum maksimal.

Dengan mengutip pendapat Horton (2003:15) yang menjelaskan bahwa ... $a$ deliberate strategy was also needed to raise the standards of its physical (infrastructure and equipment) and financial resources ... maka kenyataanya saat ini kecamatan-kecamatan di Kabupaten Bandung belum memiliki strategi

\footnotetext{
22 Analisis berdasarkan hasil wawancara dengan Sekretaris Kecamatan Rancaekek

23 Analisis berdasarkan hasil wawancara dengan Camat Rancabali
}

terencana yang dibutuhkan untuk meningkatkan standar-standar dari faktor-faktor organisasi yang bersifat fisik (infrastuktur dan peralatan) dan sumber daya keuangan. Saat ini para pimpinan kecamatan-kecamatan di Kabupaten Bandung juga belum memahami pendekatan yang lebih menyeluruh terhadap infrastruktur dan teknologi yang lebih bermanfaat dan diperlukan di masa yang akan datang.

\subsection{Perencanaan dan Pengelolaan Fasilitas, Teknologi, dan Keuangan (Planning and Management of Facilities, Technology, and Finances)}

Perencanaan dan pengelolaan fasilitas, teknologi, dan keuangan memiliki peran yang penting dalam meningkatkan kapasitas organisasi, dimana secara umum dipahami kapasitas organisasi sebagai kemampuan suatu organisasi untuk mencapai tujuannya. Dalam hal perencanaan dan pengelolaan fasilitas, teknologi dan keuangan di Kecamatan Arjasari ${ }^{24}$ untuk perencanaan fasilitas terutama yang menunjang pelaksanaan Paten disesuaikan dengan standar atau syarat yang telah di tentukan seperti adanya loket pelayanan, ruang tunggu dan lainnya disesuaikan dengan syarat pelaksanaan program Paten. Dalam perencanaan dan pengelolaan keuangan, kecamatan Arjasari melakukan perencanaan atas pengeluaran apa saja yang sekiranya dibutuhkan, contohnya untuk pelaksanaan Paten, maka tentunya diperlukan anggaran khusus agar bisa merealisasikan pembangunan pendukung program Paten. Sedangkan di Kecamatan Baleendah ${ }^{25}$ apabila terdapat kekurangan dan pihak Kecamatan Baleendah harus membeli sarana prasarana untuk menunjang kinerja pegawai, Kecamatan Baleendah harus terlebih dahulu mengajukan di tahun anggaran selanjutnya, termasuk dalam menyediakan anggaran untuk pengelolaan, perawatan serta perbaikan sarana dan prasarana tersebut.

\footnotetext{
24 Analisis berdasarkan hasil wawancara dengan Sekretaris Kecamatan Arjasari

25 Analisis berdasarkan hasil wawancara dengan Camat Kecamatan Bale Endah
} 
Untuk perencanaan dan pengelolaan fasilitas, teknologi, dan keuangan di Kecamatan Cangkuang $^{26}$ dilakukan melalui perencanaan anggaran yang diwujudkan dengan perawatan rutin terhadap fasilitas tersebut. Sedangkan dalam hal teknologi hanya digunakan sesuai kebutuhan, karena tidak semua pegawai mampu mengoperasikan teknologi yang ada. Perencanaan dan pengelolaan keuangan di Kecamatan Cangkuang diwujudkan dalam bentuk perencanaan anggaran yang disesuaikan dengan program kerja yang akan dilaksanakan di Kecamatan Cangkuang.

Perencanaan dan pengelolaan fasilitas, teknologi, dan keuangan di Kecamatan Cicalengka $^{27}$ perencanaan dan manajemen fasilitas Kecamatan Cicalengka dilakukan oleh Pemerintah Kabupaten Bandung berdasarkan peraturan perundang-undangan, sehingga pihak Kecamatan Cicalengka hanya menerima hasil dari keputusan Pemerintah Kabupaten Bandung saja tanpa ikut campur dalam melakukan perencanaan dan manajemen terhadap fasilitas kecamatan. Begitupun dengan perencanaan dan pengelolaan teknologi yang ada di Kecamatan Cicalengka, dilakukan oleh Pemerintah Kabupaten Bandung sesuai dengan peraturan yang ada. Dalam hal keuangan di Kecamatan Cicalengka, bersumber dari APBD Kabupaten Bandung, maka untuk perencanaan keuangan dilakukan pada tingkat kabupaten. Sedangkan untuk manajemen sektor keuangan, Kecamatan Cicalengka memiliki bendahara pengeluaran, bendahara penerimaan, dan bendahara gaji untuk mengatur keluar dan masuknya uang di Kecamatan Cicalengka.

Dalam hal perencanaan dan pengelolaan fasilitas, teknologi, dan keuangan di Kecamatan Cikancung $^{28}$ hanya melakukan perawatan fasilitas yang ada agar tetap sesuai dengan jumlah awalnya dan keadaan kondisi awal. Sedangkan untuk perencanaan dan pengelolaan teknologi, karena penggunaan teknologi yang ada masih

\footnotetext{
26 Analisis berdasarkan hasil wawancara dengan Sekretaris Kecamatan Cangkuang

27 Analisis berdasarkan hasil wawancara dengan Camat Cicalengka

28 Analisis berdasarkan hasil wawancara dengan Camat Cikancung
}

terbatas, sehingga tidak ada manajemen tertentu yang digunakan pihak Kecamatan Cikancung dalam perawatan teknologi yang sudah ada. Tapi pihak Kecamatan Cikancung tetap menjaganya dengan baik, dan perawatannya pun bisa dianggap baik. Dalam pengelolaan keuangan yang ada, pihak Kecamatan Cikancung menggunakan mekanisme standar yang memonitor penggunaan anggaran sesuai kebutuhan.

Sedangkan untuk perencanaan dan pengelolaan fasilitas, teknologi dan keuangan di Kecamatan Cilengkrang ${ }^{29}$ berdasarkan pedoman Paten yang dikeluarkan oleh Kementrian Dalam Negeri dan untuk pengelolaanya sudah dilaksanakan dengan baik, yakni dengan melakukan inventarisasi. Untuk perncanaan bidang keuangan juga dilakukan berdasarkan kepada pedoman Paten yang dikeluarkan oleh Kementerian Dalam Negeri dan dalam pengelolaanya terdapat pengawasan serta pengendalian melalui penyusunan maupun pelaksanaan anggaran. Sedangkan di Kecamatan Cimenyan ${ }^{30}$ dilakukan melalui perencanaan anggaran yang diwujudkan dengan perawatan rutin terhadap fasilitas tersebut. Sedangkan dalam hal perencanaan dan pengelolaan teknologi, hanya dilakukan sesuai kebutuhan tetapi tidak terlalu dominan, karena tidak semua pegawai mampu mengoperasikan teknologi yang ada. Perencanaan dan pengelolaan bidang keuangan di Kecamatan Cimenyan dilakukan dalam bentuk perencanaan anggaran yang disesuaikan dengan program kerja yang akan dilaksanakan.

Kemudian dalam hal perencanaan dan pengelolaan fasilitas, teknologi, dan keuangan di Kecamatan Dayeuhkolot ${ }^{31}$ dilakukan melalui perancangan Renstra, hanya saja tidak setiap tahun Kecamatan Dayeuhkolot mendapatkan dapat fasilitas melalui skema pengajuan kepada Pemerintah Kabupatan Bandung dengan mempertimbangkan skala prioritas kebutuhan secara bertahap. Perencanaan keuangan di kecamatan Dayeuhkolot dilakukan satu tahun sebelumnya,

\footnotetext{
29 Analisis berdasarkan hasil wawancara dengan Sekeretaris Kecamatan Cilengkrang

30 Analisis berdasarkan hasil wawancara dengan Camat Cimenyan

31 Analisis berdasarkan hasil wawancara dengan Camat Dayeuh Kolot
} 
misalnya kecamatan Dayeuhkolot mengajukan anggaran kecamatan untuk tahun 2013, pangajuaanya dilakukan di tahun 2012, dan untuk pengelolaanya disesuaikan dengan perencanaan yang diajukan. Sedangkan di Kecamatan Katapang ${ }^{32}$ untuk pengelolaan fasilitas dilakukan hanya sekedar merawat dan menjaga fasilitas yang ada.

Untuk pengelolaan teknologi, karena masih menggunakan teknologi yang biasa saja, jadi sampai saat ini pengelolaanya masih dapat terkendali dengan aman. Dalam perencanaan dan pengelolaan di bidang keuangan disesuaikan dengan peraturan mengenai keuangan negara atau keuangan daerah.

Untuk perencanaan dan pengelolaan fasilitas, teknologi, dan keuangan di Kecamatan Majalaya $^{33}$ melakukan skala prioritas yang disesuaikan dengan kebutuhan dan pengoptimalan kinerja pegawai dalam penyelenggaraan pelayanan, jika terdapat fasilitas yang rusak maka akan di perbaiki sendiri oleh pihak Kecamatan Majalaya. Hal ini dilakukan baik dalam bidang teknologi atau fasilitas lainya. Untuk bidang keuangan, peraencanaan dan pengelolaanya dilakukan dengan melihat dan menganalisis sumber daya keuangan yang dimiliki, dan juga mempetimbangkan pengeluaran lainya, seperti dana oprasional untuk perjalanan dinas dan seminar bagi pegawai.

Adapun di Kecamatan Margaasih ${ }^{34}$ perencanaan fasilitas kecamatan dimulai dengan merencanakan terlebih dahulu kebutuhan, sepesifikasi dan harga dari fasilitas tersebut setelah itu direalisasikan, begitupun dengan perencanaan dan pengelolaan di bidang teknologi. Untuk perencanaan dan pengelolaan di bidang keuangan perencanaan dilakukan mulai dari Kecamatan Margaasih terlebih dahulu, dengan menyesuaikan dengan kebutuhan, setelah itu dilakukan pengajuan untuk direalisasikan ke Pemerintah Kabupaten Bandung. Sedangkan di

\footnotetext{
32 Analisis berdasarkan hasil wawancara dengan Sekretaris Kecamatan Katapang

33 Analisis berdasarkan hasil wawancara dengan Sekretaris Kecamatan Majalaya

34 Analisis berdasarkan hasil wawancara dengan Camat Margaasih
}

Kecamatan Margahayu ${ }^{35}$ perencanaan pengelolaan cukup baik meskipun kecamatan Margahayu masih mengalami kekurangan SDM dan dana.

Dalam hal perencanaan dan pengelolaan fasilitas, teknologi, dan keuangan di Kecamatan Nagreg $^{36}$ dilakukan oleh seksi pemeliharaan prasarana umum. Di bidang keuangan, perencanaan dan pengelolaan sudah direncanakan melalui Musrenbang.

Kemudian di Kecamatan Pamengpeuk ${ }^{37}$ dengan ditetapkannya kecamatan ini sebagai salah satu kecamatan yang menyelengarakan Program Paten, maka pe-rencanaan dan pengeloaan fasilitas dan sarana pendukung penyelenggaraan Paten tersebut dilakukan berdasarkan ketetapan yang diberikan oleh Bupati Kabupaten Bandung, dengan menggunakan biaya 250 juta yang diberikan Pemerintah Daerah Kabupaten untuk keperluan sarana dan prasarana di kecamatan. Perencanaan teknologi juga dilakukan untuk mempermudah dalam pekerjaan dan juga mempermudah dalam melakukan pelayanan. Sedangkan perencanaan keuangan dilakukan sesuai dengan pedoman Peraturan Menteri Dalama Negeri Nomor 59, dimana setiap tahun pihak Kecamatan Pameungpeuk diharuskan membuat RKA (Rencana Kegiatan Anggaran).

Kemudian untuk perencanaan dan pengelolaan fasilitas, teknologi, dan keuangan di Kecamatan Pangalengan ${ }^{38}$ dilakukan sesuai dengan prosedur yang sudah ada. Dalam hal perencanaan dan pengelolaan teknologi yang ada di Kecamatan Pangalengan dilakukan dengan menganalisis kebutuhan terlebih dahulu. Perencanaan dan pengeloaan keuangan di $\mathrm{Ke}$ camatan Pangalengan dilakukan dengan menyesuaikan perencanaan anggaran alokasi yang telah dibuat.

Untuk perencanaan dan pengelolaan fasilitas, teknologi, dan keuangan di Kecamatan

\footnotetext{
35 Analisis berdasarkan hasil wawancara dengan Sekretaris Kecamatan Margahayu

36 Analisis berdasarkan hasil wawancara dengan Camat Nagreg

37 Analisis berdasarkan hasil wawancara dengan Camat Pamengpeuk

38 Analisis berdasarkan hasil wawancara dengan Sekretaris
} Kecamatan Pangalengan 
Rancaekek $^{39}$ yang berhubungan dengan penyelenggaraan Program Paten disesuaikan dengan peraturan dalam penyelenggaraan Paten itu sendiri, namun untuk fasilitas yang tidak termasuk dalam penyelenggaraan Program Paten masih belum ada perencanaan yang begitu baik. Dalam hal perencanaan teknologi dilakukan penganggaran yang diajukan setiap tahun untuk tahun kedepannya, dan dalam proses pengelolaanya disesuaikan dengan yang telah diajukan sebelumnya. Perencanaan dan pengelolaan keuangan di Kecamatan Rancaekek berawal dari pembuatan rencana anggaran untuk setahun kedepannya. Setelah RKA di sahkan, kemudian dilakukan pembuatan DPA, lalu dilakukan pencairan dana yang bisa dicairkan setiap bulan ataupun per triwulan. Dalam pencairan dana ini, pihak Kecamatan Rancaekek selalu membuat laopran dimana setiap bulannya tertera kegiatan apa saja yang menggunakan dana APBD yang sudah di anggarkan. Saat ini, sudah dilakukan pengawasan secara online oleh pemerintah Kabupaten Bandung walaupun belum berjalan maksimal, namun hal ini sangat berpengaruh terhadap kinerja kecamatan Rancaekek.

Sedangkan perencanaan dan pengelolaan fasilitas, teknologi, dan keuangan di Kecamatan Rancabali ${ }^{40}$ masih dirasakan sangat kurang baik, hal ini dapat terlihat dari penataan fasilitas yang seadanya saja dan fasilitas yang ada terlihat tidak dipelihara meskipun telah memperkerjakan orang yang bertugas menangani fasilitas tersebut. Dalam hal perencanaan dan pengeloaan teknologi, peneliti tidak melihat adanya perencanaan dan manajemen yang tepat terhadap teknologi, sebab teknologi yang ada tidak digunakan secara penuh sehingga terkesan hanya sebagai pelengkap. Perencanaan dan pengelolaan keuangan di Kecamatan Rancabali merupakan tanggung jawab dari kepala seksi keuangan kecamatan dan dikelola secara optimal sesuai anggaran yang telah direncanakan.

Dengan melihat keadaan perencanaan dan pengelolaan fasilitas, teknologi, dan keuangan oleh kecamatan-kecamatan di Kabupaten Bandung yang tergantung kepada APBD Pemerintah Kabupaten Bandung, maka dengan merujuk kepada pendapat Starling (2005:513) maka budgeting yang merupakan "the means by which public official allocate and raise resourcess to achieve social objectives" dengan demikian anggaran yang ada di APBD Kabupaten Bandung belum merepresentasikan alokasi kebutuhan kecamatan secara lengkap untuk mencapai tujuan-tujuan organisasi kecamatan di lingkungan Pemerintah Kabupaten Bandung.

\subsection{Infrastruktur, Teknologi, dan Sumber Daya Keuangan (Infrastucture, Tech- nology, and Financial Resources) Pada Kecamatan-Kecamatan Di Kabupaten Bandung}

Keberadaan faktor infrastruktur, teknologi, dan sumber daya keuangan pada organisasi kecamatan di Kabupaten Bandung masih belum mendukung sepenuhnya aktivitas kecamatan untuk dapat berperan sebagaimana yang diamanatkan oleh UU Nomor 23 Tahun 2014, padahal tugas Camat sebagaimana diatur dalam UU Nomor 23 Tahun 2014 Pasal 225 sangatlah banyak. Dengan 9 (sembilan) tugas pokok camat yang demikian luasnya tentu tidak dapat terlaksana dengan baik apabila tidak didukung dengan infrastruktur, teknologi, dan sumber daya keuangan yang memadai bagi organisasi kecamatan di Kabupaten Bandung. Berkaitan dengan anggaran secara umum ${ }^{41}$ bahwa APBD yang disalurkan ke kecamatan setiap tahun berada di Bapedda seperti belanja langsung, program, dan belanja tidak langsung. Begitu pula untuk Kabupaten Bandung mengenai besaran presentasi APBD yang disalurkan datanya berada di Bapedda. Sebagai contoh penggunaan dana dari APBD di Kabupaten Bandung, yaitu dimana setiap kecamatan menerima 250 juta untuk menerapkan Program

\footnotetext{
39 Analisis berdasarkan hasil wawancara dengan Sekretaris Kecamatan Rancaekek

40 Analisis berdasarkan hasil wawancara dengan Camat Rancabali
} 41 Analisis berdasarkan hasil wawancara dengan Staf Bappeda
Kabupaten Bandung 
Pelayanan Administrasi Terpadu Kecamatan (Paten) untuk membeli sistem, perangkat IT, dan alat-alat kantor. Dana tersebut sepenuhnya berasal dari APBD, sama sekali tidak ada bantuan dari APBN. Dana 250 juta itu diberikan pada saat pembangunan saja bukan setiap tahun diberikan.

Sama halnya dengan kecamatan ${ }^{42}$ bukan hanya di desa saja, di 10 (sepuluh) kelurahan yang ada di Kabupaten Bandung juga sudah menerapkan Paten Kelurahan dengan menerima masing-masing 150 juta yang disesuaikan dengan ruang lingkupnya. Pemerintah Kabupaten Bandung tidak menyimpan anggaran di desa dan kelurahan, tetapi sudah ada anggarannya di kecamatan-kecamatan di Kabupaten Bandung. Hal tersebut untuk merespon secara cepat permasalahan masyarakat. Anggaran itu muncul dan diturunkan untuk menjawab masalah kewilayahan masyarakat.

Sebenarnya Pemerintah Pusat ${ }^{43}$ telah mengatur bahwa pendanaan tugas camat dalam penyelenggaraan tugas umum pemerintahan dan pelaksanaan sebagian wewenang bupati yang dilimpahkan bersumber dari anggaran pendapatan dan belanja daerah kabupaten. Bahkan di dalam kebijakan yang baru telah diatur bahwa pendanaan bagi organisasi kecamatan ${ }^{44}$ berasal dari 3 (tiga) sumber, yaitu: pendanaan penyelenggaraan urusan pemerintahan umum (tugas 1) dibebankan pada APBN. Selanjutnya pendanaan dalam penyelenggaraan tugas pemerintahan yang dilakukan oleh camat (tugas 2 sampai 8) serta (tugas pelimpahan sebagian kewenangan bupati/wali kota) dibebankan pada APBD kabupaten/kota. Sedangkan pendanaan pelaksanaan tugas lain (tugas 9) dibebankan kepada lembaga yang menugasi. Demikian pula pada kebijakan yang sama dalam pasal yang lain ${ }^{45}$ disebutkan bahwa pendanaan dalam penyelenggaraan tugas pemerintahan yang dilakukan oleh camat yang terkait dengan tugas pokok camat dan pelimpahan kewenangan bupati

\footnotetext{
42 Analisis berdasarkan hasil wawancara dengan Staf Bappeda Kabupaten Bandung

43 Hal ini diatur dalam Peraturan Pemerintah No. 19 Tahun 2008 Tentang Kecamatan, Pasal 29 dan Pasal 33.

44 Undang-Undang No. 23 Tahun 2014 Tentang Pemerintahan Daerah, Pasal 225, Ayat 2
}

dibebankan pada APBD kabupaten/kota.

Berdasarkan penelitian lapangan, bahwa untuk kewenangan Camat dalam pemerintahan umum anggarannya dari APBN yang dititipkan ke APBD $^{46}$. Mekanismenya yaitu jika APBD tidak ada masalah seperti DAU saja, yang diikuti dengan pedoman dalam rangka penyelenggaraan kewenangan pemerintahan umum. Ada pula bantuan-bantuan keuangan yang bersifat khusus dan bersifat umum. Bantuan yang bersifat khusus dilengkapi dengan dana petunjuk, sedangkan bantuan bersifat umum diserahkan kepada penerima bantuan kegiatannya. Pedoman tersebut masih menggunakan PP 19 Tahun 2008. Kalau DAK berasal dari Kementerian misalnya dana pendidikan, DAK itu banyak yang digugat oleh daerah karena tidak fleksibel dan membutuhkan juknis, jika juknisnya terlambat maka banyak DAK yang tidak terserap. Seperti contoh dana pendidikan pada tahun 2014/2015 tidak dapat dilaksanakan karena juknis yang terlambat. Walaupun ada dana pendamping DAK (dari APBD) yaitu 20 persen dari dana pembantuan, namun hal tersebut belum mencukupi untuk biaya kebutuhan urusan wajib.

Camat mendapatkan pelimpahan sebagian kewenangan Bupati ${ }^{47}$ untuk melaksanakan sebagian Urusan Pemerintahan yang menjadi kewenangan Daerah Kabupaten. Pelimpahan kewenangan Bupati dilakukan berdasarkan pemetaan pelayanan publik yang sesuai dengan karakteristik Kecamatan dan/atau kebutuhan masyarakat pada Kecamatan yang bersangkutan. Namun demikian pelimpahan sebagian kewenangan Bupati Bandung kepada Camat untuk melaksanakan sebagian Urusan Pemerintahan tersebut tidak bisa berjalan dengan efektif, karena infrastruktur, teknologi, dan sumber daya keuangan belum mendukung organisasi $\mathrm{Ke}$ camatan di Kabupaten Bandung. Selain itu, variasi beban kewilayahan antar Kecamatan juga tidak hanya terkait dengan cakupan wilayah fisik semata dan karakter demografis semata.

\footnotetext{
45 Undang-Undang No. 23 Tahun 2014 Tentang Pemerintahan Daerah, Pasal 227.

46 Analisis berdasarkan hasil wawancara dengan Staf Bappeda Kabupaten Bandung

47 Analisis berdasarkan hasil Analisis berdasarkan hasil wawancara dengan anggota DPRD Kabupaten Bandung.
} 
Kompleksitas dan kedalaman persoalan ekonomi dan sosial yang ada di masing-masing Kecamatan di Kabupaten Bandung juga berbeda satu sama lain.

Dalam hal infrastruktur pada setiap kecamatan di Kabupaten Bandung ${ }^{48}$ saat ini terus ditingkatkan kualitas dan kuantitasnya. Infra- struktur dan anggaran diharapkan berbanding lurus untuk memenuhi kebutuhan masyarakat dalam hal pelayanan publik. Masih banyak infrastruktur yang terkait dengan kecamatan yang kondisinya kurang layak, hal tersebut dapat dilihat pada tabel berikut ini.

Tabel 4.21 Beberapa Infrastruktur Kecamatan di Kabupaten Bandung

\begin{tabular}{|c|c|c|c|c|c|c|c|c|}
\hline NO & KECAMATAN & $\begin{array}{l}\text { Gedung } \\
\text { Kantor }\end{array}$ & Rumah Dinas & Aula & Pagar & Alun-Alun & Musholla & $\begin{array}{c}\text { RTH / } \\
\text { Halaman }\end{array}$ \\
\hline 1 & Cileunyi & Baik & Baik & Baik & Baik & Baik & Baik & Baik \\
\hline 2 & Cimenyan & Baik & Baik & Baik & Baik & Tidak Ada & Sedang & Tidak Ada \\
\hline 3 & Cilengkrang & Kurang Baik & Kurang Baik & Kurang Baik & Kurang Baik & Kurang Baik & Kurang Baik & Kurang Baik \\
\hline 4 & Bojongsoang & Baik & Baik & Sedang & Baik & Tidak Ada & Sedang & Baik \\
\hline 5 & Margahayu & Kurang Baik & Kurang Baik & Kurang Baik & Kurang Baik & Tidak Ada & Kurang Baik & Tidak Ada \\
\hline 6 & Margaasih & Baik & Baik & Baik & Baik & Tidak Ada & Baik & Baik \\
\hline 7 & Katapang & Baik & Baik & Rusak & Baik & Tidak ada & Rusak & Tidak Ada \\
\hline 8 & Banjaran & Baik & Baik & Baik & Baik & Baik & Tidak ada & Baik \\
\hline 9 & Pameungpeuk & Kurang Baik & Kurang Baik & Kurang Baik & Kurang Baik & Tidak Ada & Kurang Baik & Tidak Ada \\
\hline 10 & Pangalengan & Baik & Baik & Baik & Tidak ada & Baik & Baik & Tidak Ada \\
\hline 11 & Arjasari & Baik & Baik & Baik & Baik & Tidak Ada & Baik & Sedang \\
\hline 12 & Cimaung & Baik & Baik & Baik & Baik & Baik & Baik & Baik \\
\hline 13 & Cicalengka & Baik & Baik & Baik & Baik & Baik & Baik & Baik \\
\hline 14 & Nagreg & Baik & Baik & Baik & Baik & Tidak ada & Kurang Baik & Tidak Ada \\
\hline 15 & Cikancung & Baik & Baik & Baik & Baik & Tidak Ada & Baik & Baik \\
\hline 16 & Rancaekek & Baik & Baik & Baik & Sedang & Tidak Ada & Sedang & Sedang \\
\hline 17. & Ciparay & Baik & Baik & Baik & Baik & Baik & Baik & Baik \\
\hline 18. & Pacet & Baik & Sedang & Sedang & Sedang & Tidak ada & Rusak & Sedang \\
\hline 19. & Kertasari & Baik & Baik & Baik & Baik & Tidak Ada & Kurang Baik & Tidak Ada \\
\hline 20. & Baleendah & Baik & Baik & Sedang & Sedang & Tidak Ada & Sedang & Baik \\
\hline 21. & Majalaya & Baik & Baik & Baik & Baik & Baik & Baik & Baik \\
\hline 22. & Solokanjeruk & Baik & Baik & Baik & Baik & Tidak Ada & Sedang & Baik \\
\hline 23. & Paseh & Sedang & Baik & Baik & Baik & Tidak Ada & Sedang & Baik \\
\hline 24. & Dayeuhkolot & Baik & Tidak ada & Baik & Baik & Tidak Ada & Sedang & Sedang \\
\hline 25. & Ibun & Baik & Baik & Baik & Baik & Baik & Kurang Baik & Tidak Ada \\
\hline 26. & Soreang & Baik & Baik & Baik & Baik & Tidak Ada & Sedang & Tidak Ada \\
\hline 27. & Pasirjambu & Baik & Baik & Rusak & Rusak & Tidak Ada & Rusak & Sedang \\
\hline 28. & Ciwidey & Baik & Rusak & Sedang & Sedang & Sedang & Baik & Baik \\
\hline 29. & Rancabali & Baik & Baik & Baik & Baik & Tidak Ada & Baik & Baik \\
\hline 30. & Cangkuang & Baik & Baik & Baik & Baik & Tidak Ada & Baik & Baik \\
\hline 31. & Kutawaringin & Baik & Baik & Baik & Baik & Tidak Ada & Baik & Baik \\
\hline
\end{tabular}

(Sumber : Penulis mengolah dari berbagai data sekunder yang ada pada Bagian Pemerintahan Umum Sekretariat Daerah Kabupaten Bandung, 2017)

48 Analisis berdasarkan hasil wawancara dengan Kabag Pemerintahan Umum 
Kebutuhan infrastruktur ditingkatkan agar masyarakat merasa nyaman dengan pelayanan yang diberikan di lingkungan kecamatan Kabupaten Bandung, karena tidak hanya di kantor kecamatan yang ditingkatkan fasilitas infrastrukturnya, tetapi juga lingkungan kecamatan secara luas seperti taman-taman yang bisa dijadikan sarana bagi masyarakat dalam merasakan fasilitas publik. Dalam hal infrastruktur dan teknologi ${ }^{49}$ dalam sistem rekapitulasi data tiap lembaga mempunyai cara yang berbedabeda. Saat ini tiap-tiap kecamatan belum memiliki rekap data yang lengkap, misalnya data di seksi pemerintahan. Selain itu sistem yang ada di Bapedda dengan sistem yang ada di berbagai Perangkat Daerah lainnya belum integrasi, hanya baru dibangun Bapapsi, selanjutnya diintegrasikan semua kebutuhan yang ada di perangkat daerah sehingga menjadi satu data di Kabupaten Bandung, tetapi itu juga tergantung dari masingmasing pimpinan perangkat daerah untuk dapat bersinkronisasi dalam setiap kegiatannya dengan organisasi kecamatan di Kabupaten Bandung.

Organisasi kecamatan merupakan salah satu perangkat daerah yang memberikan pelayanan secara langsung dan memiliki peran strategis dalam upaya mendekatkan pelayanan publik kepada masyarakat di Kabupaten Bandung, terlebih perannya yang begitu besar sebagaimana diamanatkan melalui UU Nomor 23 Tahun 2014. Dengan kata lain, tuntutan peningkatan kapasitas organisasi kecamatan pasca berlakunya UU 23 Tahun 2014 menjadi suatu keharusan guna meningkatkan kualitas pelayanan publik di kecamatan. Perkembangan organisasi kecamatan tidak dapat dipisahkan dari Pemerintahan Daerah yang diatur dalam UU Nomor 23 Tahun 2014.

Dalam faktor infrastruktur, teknologi, dan keuangan, hasil temuan lapangan melalui wawancara kepada Kepala Bagian Organisasi serta Kepala Bidang di Dinas Kependudukan dan Catatan Sipil, pada dasarnya Pemerintah Kabupaten Bandung berupaya mendekatkan pelayanan kepada masyarakat melalui penerapan teknologi. Terlebih, peran kecamatan melalui penerapan Paten (Pelayanan Administrasi Terpadu Kecamatan) serta pasca diberlakukannya UU No. 23 Tahun 2014 dan PP No. 18 Tahun 2016, peran kecamatan sebagai simpul pelayanan publik menjadi semakin besar.

Pada dasarnya, dukungan teknologi di kecamatan guna mempermudah pelayanan di kecamatan khususnya pelayanan administrasi kependudukan menggunakan Sistem Informasi Administrasi Kependudukan atau yang biasa dikenal dengan istilah SIAK. SIAK merupakan system yang dibentuk oleh Kementerian Dalam Negeri dalam upaya mendekatkan pelayanan kepada masyarakat dan guna mewujudkan sistem catatan kependudukan yang tertib. Namun demikian, dukungan sumber daya manusia khususnya operator SIAP tentu diperlukan. Terlebih, SIAK merupakan suatu sistem yang baru dikenal. Menurut di Bagian Organisasi Pemerintah Kabupaten Bandung, Rekrutmen operator SIAK dilaksanakan pada tahun 2011 oleh setiap kecamatan dan pada tahun 2014 dilakukan seleksi oleh Dinas Kependudukan dan Catatan Sipil Kabupaten Bandung sehingga operator SIAK menjadi pegawai yang berada dalam kendali dari Dinas Kependudukan dan Catatan Sipil yang ditempatkan di kecamatan guna mendekatkan pelayanan kepada masyarakat, khususnya masyarakat Kabupaten Bandung dengan berbagai karakteristiknya. Hal ini diperkuat pula oleh pernyataan Kepala Bidang Pendaftaran Penduduk Pemerintah Kabupaten Bandung yang menyatakan hal senada. Dengan demikian, dalam hal dukungan anggaran belanja pegawai bagi operator SIAK yang ditempatkan di kecamatan, hal ini dibebankan kepada Dinas Kependudukan dan Catatan Sipil Pemerintah Kabupaten Bandung.

Selain temuan diatas, permasalahan lainnya yang ditemukan peneliti dilapangan adalah ketersediaan prasarana telekomunikasi. Hal ini dikemukakan oleh Staf Pengelola Data Kependudukan yang menyatakan bahwa seringkali proses perekaman data kependudukan terhambat oleh buruknya sinyal telekomunikasi yang ada di wilayah kecamatan. Guna mengatasi

49 Analisis berdasarkan hasil wawancara dengan Staf Bappeda Kabupaten Bandung 
hal tersebut, proses perekaman data kependudukan seringkali dilakukan secara manual.

Data terakhir yang dimiliki oleh Bapedda Kabupaten Bandung menunjukkan bahwa pad atahun 2010 sd. 2015 faktor ketersediaan teknologi sebagai sarana penunjang pelayanan publik di wilayah Kabupaten Bandung masih rendah, walupun demikian sudah ada peningkatan dari tahun ke tahun, hal ini dapat dilihat dalam tabel ketersediaan sarana atau akses internet berikut ini. warah Perencanaan Pembangunan yang melibatkan pendekatan top down berupa usulan dari Perangkat Daerah terkait, dan bottom up berupa partisipasi masyarakat, serta pendekatan teknokratik. Pendekatan bottom up berasal dari aspirasi masing-masing wilayah dengan melihat kebutuhan dan persoalan yang dihadapi. Pendekatan top down berasal dari Perangkat Daerah dengan melihat pada persoalan sektoral yang ditanganinya. Sementara pendekatan teknokratik berasal dari pemikiran dan perumusan prioritas pembangunan. Perencanaan

\section{Tabel 4.24 Daftar Ketersediaan Sarana/Prasarana (Teknologi) Komunikasi Dan Informasi di Kabupaten Bandung Tahun 2010 - 2015}

\begin{tabular}{|c|l|c|c|c|c|c|c|}
\hline No. & $\begin{array}{l}\text { Sarana/Prasarana } \\
\text { (Teknologi) Komunikasi Dan } \\
\text { Informasi }\end{array}$ & $\mathbf{2 0 1 0}$ & $\mathbf{2 0 1 1}$ & $\mathbf{2 0 1 2}$ & $\mathbf{2 0 1 3}$ & $\mathbf{2 0 1 4}$ & $\mathbf{2 0 1 5}$ \\
\hline 1. & $\begin{array}{l}\text { Jumlah Perangkat Daerah Yang } \\
\text { Memiliki Akses Internet }\end{array}$ & 100 & 28 & 28 & 72 & 72 & 72 \\
\hline 2. & $\begin{array}{l}\text { Jumlah Sistem Informasi yang } \\
\text { Ada }\end{array}$ & 38 & 38 & 38 & 38 & 38 & 61 \\
\hline 3. & $\begin{array}{l}\text { Jumlah Titik Hotspot Yang } \\
\text { Difasilitasi Pemerintah Daerah }\end{array}$ & 5 & 5 & 5 & 5 & 5 & 5 \\
\hline
\end{tabular}

Sumber: Bapedda Kabupaten Bandung, 2016 program dan kegiatan prioritas ini juga meliputi target pencapaian beserta indikatornya dan penganggaran yang akan dibebankan pada APBD kabupaten serta waktu dan lokasi pelaksanaannya.

Penguatan faktor infrastruktur dan teknologi dalam pembangunan daerah akan tergantung pada kemauan Pemerintah Kabupaten Bandung terhadap kecamatan. Jika pada akhirnya kelurahan dan desa diperkuat sebagai ujung tombak pelayanan publik maka implikasinya kecamatan hanya akan menjalankan fungsi yang relatif minor, misalnya koordinasi. Namun, kalau organisasi kecamatan di Kabupaten Bandung yang diperkuat, kelurahan/desa akan menjadi institusi penopang bagi fungsi-fungsi kecamatan. Di Kabupaten Bandung, pemerintah daerah cukup jelas saat ini sudah mulai memperkuat kecamatan sebagai basis pelayanan publik.

\section{PENUTUP}

\subsection{Simpulan}

Saat ini kecamatan-kecamatan di Kabupaten Bandung belum memiliki strategi terencana yang dibutuhkan untuk meningkatkan standar-standar dari faktor-faktor organisasi yang bersifat fisik (infrastuktur dan peralatan) dan kegiatannya ini berasal dari mekanisme Musyabeberapa sasaran. Program ini kemudian dideskripsikan lagi dalam bentuk kegiatankegiatan yang menjadi alat utama dalam mencapai sasaran-sasaran yang telah ditetapkan tersebut. Rencana program beserta kegiatan- 
sumber daya keuangan dalam melaksanakan program Pelayanan Administrasi Terpadu Kecamatan (Paten). Para pimpinan kecamatankecamatan di Kabupaten Bandung juga belum memahami pendekatan yang lebih menyeluruh terhadap infrastruktur dan teknologi yang lebih bermanfaat dan diperlukan di masa yang akan datang.

Untuk perencanaan dan pengelolaan fasilitas, teknologi, dan keuangan di Kecamatan dalam melaksanakan program Pelayanan Administrasi Terpadu Kecamatan (Paten) dilakukan melalui perencanaan anggaran yang diwujudkan dengan perawatan rutin terhadap fasilitas tersebut. Sedangkan dalam hal teknologi hanya digunakan sesuai kebutuhan, karena tidak semua pegawai mampu mengoperasikan teknologi yang ada. Perencanaan dan pengelolaan keuangan di Kecamatan diwujudkan dalam bentuk perencanaan anggaran yang disesuaikan dengan program kerja yang akan dilaksanakan di Kecamatan.

Perencanaan dan pengelolaan fasilitas, teknologi, dan keuangan di Kecamatan dalam melaksanakan program Pelayanan Administrasi Terpadu Kecamatan (Paten) dilakukan oleh organisasi di tingkat atasnya, sehingga pihak Kecamatan hanya menerima hasil dari keputusan Pemerintah Kabupaten Bandung saja tanpa ikut campur dalam melakukan perencanaan dan manajemen terhadap fasilitas kecamatan. Begitupun dengan perencanaan dan pengelolaan teknologi yang ada di Kecamatan, dilakukan oleh sesuai dengan peraturan yang ada. Dalam hal keuangan di Kecamatan bersumber dari APBD Kabupaten Bandung, maka untuk perencanaan keuangan dilakukan pada tingkat kabupaten. Sedangkan untuk manajemen sektor keuangan, Kecamatan memiliki bendahara pengeluaran, bendahara penerimaan, dan bendahara gaji untuk mengatur keluar dan masuknya uang di Kecamatan.

Perencanaan dan pengelolaan fasilitas, teknologi, dan keuangan di Kecamatan masih dirasakan sangat kurang baik dalam melaksanakan program Pelayanan Administrasi Terpadu Kecamatan (Paten), hal ini dapat terlihat dari penataan fasilitas yang seadanya saja dan fasilitas yang ada terlihat kurang terpelihara. Dalam hal perencanaan dan pengeloaan teknologi, belum ada perencanaan dan manajemen yang tepat terhadap teknologi, sebab teknologi yang ada tidak digunakan secara penuh sehingga terkesan hanya sebagai pelengkap. Perencanaan dan pengelolaan keuangan di Kecamatan saat ini menjadi tanggung jawab dari kepala seksi keuangan kecamatan dan dikelola secara optimal sesuai anggaran yang telah direncanakan.

Dengan melihat keadaan perencanaan dan pengelolaan fasilitas, teknologi, dan keuangan dalam melaksanakan program Pelayanan Administrasi Terpadu Kecamatan (Paten) di Kabupaten Bandung yang tergantung kepada APBD Pemerintah Kabupaten Bandung, maka anggaran yang ada di APBD Kabupaten Bandung belum merepresentasikan kebutuhan kecamatan secara lengkap untuk mencapai tujuan-tujuan organisasi kecamatan di lingkungan Pemerintah Kabupaten Bandung.

\subsection{Saran}

1. Pemerintah Kabupaten Bandung harus memberikan strategi terencana yang dibutuhkan kecamatan-kecamatan dalam melaksanakan program Pelayanan Administrasi Terpadu Kecamatan (Paten) di Kabupaten Bandung dengan pendekatan yang lebih menyeluruh terhadap infrastruktur dan teknologi yang lebih bermanfaat dan diperlukan saat ini serta untuk masa yang akan datang.

2. Kecamatan-kecamatan di Kabupaten Bandung dalam melakukan perencanaan dan pengelolaan fasilitas, teknologi, dan keuangan dalam melaksanakan program Pelayanan Administrasi Terpadu Kecamatan (Paten) dalam melaksanakan program Pelayanan Administrasi Terpadu Kecamatan (Paten) sebaiknya menyertakan anggaran untuk perawatan rutin terhadap fasilitas tersebut.

3. Perlu adanya peningkatan kemampuan sumber daya manusia kecamatan untuk dapat mengoperasikan teknologi yang ada. Perencanaan dan pengelolaan keuangan di 
Kecamatan diwujudkan dalam bentuk perencanaan anggaran dalam melaksanakan program Pelayanan Administrasi Terpadu Kecamatan (Paten) yang disesuaikan dengan program kerja peningkatan kemampuan sumber daya manusia kecamatan yang akan dilaksanakan di Kecamatan.

4. Perencanaan dan pengelolaan fasilitas, teknologi, dan keuangan dalam melaksanakan program Pelayanan Administrasi Terpadu Kecamatan (Paten) sebaiknya dapat dilakukan oleh organisasi di tingkat kecamatan saja, sehingga pihak kecamatan dapat dengan leluasa melakukan perencanaan dan manajemen terhadap fasilitas kecamatan. Dengan demikian penataan fasilitas dapat lebih terpelihara langsung oleh kecamatan.

5. Alokasi anggaran yang ada di APBD Kabupaten Bandung seharusnya lebih merepresentasikan kebutuhan kecamatan secara lengkap, dengan demikian peningkatan alokasi anggaran kecamatan agar diprioritaskan untuk dapat memperlancar aktivitas-aktivitas organisasi kecamatan di lingkungan Pemerintah Kabupaten Bandung.

\section{DAFTAR PUSTAKA}

Boyne, George A et.all editors. 2006. Public Service Performance: Perspectives on Measurement and Management, Cambridge: Cambridge Iniversity Press.

Cohen, Steven and William Eimicke, 2002. The Effective Public Managers: Achieving Sicces in a Changing Government, Third edition, Bellmont, California: Wordsworth Publishing Company.

Creswell, John W, 2009, Research Design: Qualitative, Quantitative, and Mixed Methods Approacges, Third Edition, California: Sage Publication, Inc.
Daft, Ricard L, 2002, Organization and Design, Ohio: South-Western College Publishing

Horton, Douglas, Et. All, 2003, Evaluating Capacity Development : Experiences From Research And Development Organizations Around The World. The Netherlands: International Service for National Agricultural Research (ISNAR); Canada: International Development Research Centre (IDRC), the Netherlands: ACP-EU Technical Centre for Agricultural and Rural Cooperation (CTA).

Jones, Gareth, R. 2004. Organizational Theory, Design, And Change: Text and cases, Forth Edition, New York: Pearson, Pretice Hall

Lusthaus, Charless, et,.all, 2002. Organizational Assessment. A framework for improving performance. Ottawa: Inter-American Development Bank, Washington DC and International Development Research Centre.

Mardiasmo, 2002, Otonomi Daerah dan Manajemen Keuangan Daerah, Yogyakarta: Andi.

Rosenbloom, David H., Robert Kravchuk and Richard M. Clerkin. 2009. Public Administration: Understanding Management, Politics, in Law in the Public Sector, $7^{\text {th }}$ Edition, New York: McGrawHill International Edition.

Starling, Grover. 2005. Managing Public Sector, Seventh Edition, Thompson Wadsworth, United States.

Wandiga, Shem Oyoo. 1997. Capacity Building And Institutional Development in Higher Education in Kenya, A Case Study of Public Universities Investment Project (1991-1994). Paris : UNESCO International Institute for Educational Planning. 